\title{
POTRET PENDIDIKAN, UPAH DAN SOSIAL BUDAYA SERTA TINGKAT KEMISKINAN DI KAMPUNG ANGGRIS KECAMATAN PAGEDANGAN KABUPATEN TANGERANG TAHUN 2016
}

\author{
SAIFUL ANWAR ${ }^{1)}$, SYAFAATUL HIDAYATI ${ }^{2)}$, HAERUDIN $^{3)}$ \\ ${ }^{1,2}$ Dosen Pendidikan Ekonomi, Universitas Pamulang \\ ${ }^{3}$ Mahasiswa Pendidikan Ekonomi, Universitas Pamulang \\ $\underline{\text { dosen00902@unpam.ac.id }}^{1}, \underline{\text { dosen861@unpam.ac.id }}^{2}$
}

\begin{abstract}
ABSTRAK
Penelitian ini mengkaji secara mendalam beberapa faktor yang mempengaruhi tingkat kemiskinan di Kampung Anggris Kecamatan Pagedangan Kabupaten Tangerang pada tahun 2016, penelitian ini menggunakan rancangan penelitian kualitatif dalam hal ini peneliti bertindak sebagai instrumen utama. Data yang dihasilkan dari penelitian ini adalah hasil wawancara, observasi dan dokumentasi. Adapun subjek penelitian ini adalah masyarakat Kampung Anggris Kecamatan Pagedangan Kabupaten Tangerang pada tahun 2016 dimana penelitian ini dilakukan mulai bulan Februari 2016 sampai dengan Agustus 2017. Dalam pengumpulan data menggunakan metode wawancara dengan 1 (satu) orang key informan dan 5 (lima) orang informan, ditambah dengan observasi dan dokumentasi. Temuan penelitian ini menunjukan hal-hal sebagai berikut: Faktorfaktor yang mempengaruhi kemiskinan di Kabupaten Tangerang dipengaruhi oleh tingkat pendidikan yang rendah, beban keluarga, upah minimum, tingginya angka pendidikan yang rendah adalah masalah yang paling dominan yang terdapat di Kampung Anggris.
\end{abstract}

Kata Kunci: tingkat kemiskinan, Masyarakat Kampung Anggris 2016

\section{PENDAHULUAN}

Penelitian ini mengkaji secara mendalam faktor tingkat upah, tingkat pendidikan dan sosial budaya serta dampaknya pengaruhnya terhadap tingkat kemiskinan di Kampung Anggris Kecamatan Pagedangan Kabupaten Tangerang pada tahun 2016, rancangan penelitian yang dipergunakan dalam penelitian ini adalah penelitian kualitatif dalam hal ini peneliti bertindak sebagai instrumen utama. Data yang dihasilkan dari penelitian ini adalah hasil wawancara, observasi dan dokumentasi. Adapun subjek penelitian ini adalah masyarakat Kampung Anggris 
Kecamatan Pagedangan Kabupaten Tangerang pada tahun 2016 dimana penelitian ini dilakukan mulai bulan Februari 2016 sampai dengan Agustus 2017. Dalam pengumpulan data menggunakan metode wawancara dengan 1 (satu) orang key informan dan 5 (lima) orang informan, ditambah dengan observasi dan dokumentasi.

Temuan penelitian ini menunjukan hal-hal sebagai berikut: Faktor-faktor yang mempengaruhi kemiskinan di Kabupaten Tangerang dipengaruhi oleh tingkat pendidikan yang rendah, beban keluarga, upah minimum, tingginya angka pendidikan yang rendah adalah masalah yang paling dominan yang terdapat di Kampung Anggris.

Setelah melihat hasil penelitian ini, diharapkan pihakpihak yang berkepentingan lebih jeli dalam melihat kondisi masyarakat secara menyeluruh dan menanamkan arti pentingnya pendidikan sebagai bekal dasar dalam memperoleh pekerjaan yang layak. Sehingga, pendapatan masyarakat menjadi lebih baik dalam memenuhi kebutuhan hidupnya.

Dari ketiga faktor yang mempengaruhi kemiskinan yang disinyalir terdampak terhadap tingginya angka kemiskinan adalah tingkat pendidikan rendah, dikarenakan dengan pendidikan yang rendah akan suli sekali untuk mendapatkan upah yang layak dalam setiap kesempatan kerja yang ada, sehingga butuh keterampilan khusus untuk mendapatkan pekerjaan dengan upah yang layak. Dengan meningkatkan pendidikan diharapkan setiap individu dapat menjadi pegawai dengan kwalitas yang bagus atau memenuhi standar yang ada secara tidak langsung hal inilah yang dapat menekan tingginya angka pengangguran yang ada sehingga secara tidak langsung dengan tingkat pendidikan yang tinggi akan mengurangi angka kemiskinan yang ada.

Faktor selanjutnya yang disinyalir dapat menyebabkan meningkatnya angka kemiskinan adalah kebutuhan keluarga, terlebih bagi keluarga yang anggotanya melebihi kapasitas yang ditanggung, karena semakin besar anggota keluarga yang ditanggung maka akan semakin besar biaya yang dikeluarkan untuk kebutuhan konsumsi sehari-hari, terlebih jika sipenangung atau tulang punggung keluarga hanya sendiri dengan upah yang minimum pula, hal demikian akan makin membutuhkan biaya yang lebih besar untuk pemenuhannya, sehingga tidak jarang orang akan cenderung berhutang untuk memenuhinya, kalau hal ini terjadi terus menerus disinyalir angka kemiskinan yang ada akan semakin tinggi.

Desa Anggris merupakan desa yang strategis dengan dikelilingi pusat-pusat layanan umum yang lengkap seperti: rumah sakit dan pusat-pusat perbelanjaan ada disekitar desa ini, namun hal ini seperti tidak ada manfaatnya bagi masyarakat yang ada di Desa 
Anggris ini, karena sebagian besar masyarakat disini hanya sedikit yang dapat bekerja di perusahaanperusahaan yang tersebar di wilayah sekitarnya tinggal, dengan demikian kemajuan yang ada masih sangat jauh dirasakan oleh masyarakat Desa Anggris, ketimpangan ini akan makin terasa apabila kita terus menyusuri kampung ini yang makin lama makin kecil, rumah-rumah penduduk asli makin sedikit yang masih bertahan di sini, pembangunan perumahan dan gedung-gedung serta apartemen semakin menggerus hunian para penduduk asli, sehingga semakin kecil pula kesempatan masyarakat Desa Anggir ini yang mampu bersaing untuk mendapatkan pekerjaan yang layak yang terdapat di sekitarnya tinggal, sehingga sebagian besar masyarakat desa ini bekerja sebagai tukang ojek bagi para prianya atau buruh cuci bagi para wanitanya, sungguh semakin memilukan kondisi ini semakin hari sedangkan andil pemerintahan untuk mempertahankan Desa ini belum terasa dampaknya.

Tingkat kesenjangan sosial yang semakin tinggi dialami masyarakat asli Desa Anggris, dimana pemukiman penduduknya semakin tergusur habis oleh pembangunan perumahanperumahan dan sarana-sarana umum lainnya, sementara masyarakat tidak menikmati hasil dari pembangunan tersebut bahkan membuat masyarakat asli makin tersudut kedalam kemiskinan karena biaya hidup di daerahnya semakin tinggi, sementara kesulitan mendapatkan pekerjaan, terlebih dengan upah yang layak.

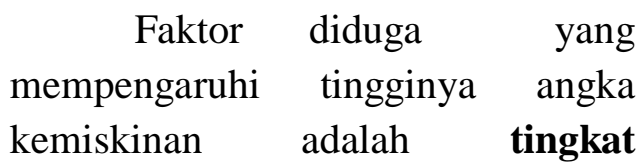

pendidikan yang rendah. Desa Anggris termasuk desa yang tingkat pendidikan masyarakatnya masih terbilang sangat rendah di bandingkan desa-desa yang lain yang ada diwilayah Kabupaten Tangerang. Hal ini disebabkan tidak adanya kesadaran masyarakat akan pentingnya pendidikan baik dari pihak individunya sendiri maupun keluarganya. Rata-rata tingkat pendidikan mereka hanya sampai sekolah lanjutan tingkat pertama (SLTP), kalau kita amati pendidikan merupakan pondasi yang sangat penting untuk menopang kehidupan kita. Dengan pendidikan yang tinggi masyarakat dapat mencari pekerjaan yang layak dan posisi pekerjaan yang bagus melalui keilmuan dan keterampilan. Dan pada akhirnya tentu akan mebuat kenaikan produktivitas kerja dan berpeluang memperoleh penghasilan yang lebih baik.

$\begin{array}{lrr} & \text { Faktor diduga } & \text { berikutnya } \\ \text { yang mempengaruhi } & \text { tingkat } \\ \text { kemiskinan adalah } & \text { kebutuhan } \\ \text { keluarga, kebutuhan } & \text { konsumsi }\end{array}$
keluarga yang semakin hari semakin besar dengan tidak disertai penghasilan yang memadai maka akan makin meningkatkan angka kemiskinan, masyarakat Desa Anggris kebanyakan penduduknya hanya mengandalkan lahan-lahan 
parkir dan pangkalan-pangkalan ojek untuk dijadikan sebagai mata pencahariannya. Padahal pendapatan dari itu sangat jauh dari kata cukup untuk memenuhi kebutuhan keluarga.

Faktor diduga lainnya yang mempengaruhi tingkat kemiskinan adalah upah minimum, kemampuan dan keterampilan seseorang yang di dapat dari pendidikan akan membawa dampak yang positif terhadap pemberian upah yang layak. Apabila seseorang memiliki riwayat pendidikan yang baik diharapkan akan memiliki kemampuan dan keterampilan yang baik pula sehingga diharapkan akan mendapatkan pekerjaan yang layak dengan upah yang layak pula sehingga pemenuhan kebutuhan sehari-hari akan terpenuhi dengan baik.

\section{METODE PENELITIAN}

Metode penelitian yang peneliti gunakan adalah penelitian kualitatif, pendekatan ini digunkan apabila masalah penlitian belum jelas, masih remang-remang atau bahkan masih gelap, metode kualitatif sangat cocok diterapkan pada kondisi semacam ini karena peneliti akan langsung masuk kelapangan sehingga masalah akan ditemukan dengan jelas.

Kehadiran peneliti sangat diperlukan untuk melakukan pengamatan secara langsung dilapangan. Peneliti mengamati situasi di lokasi penelitian yaitu di Desa Anggris, dan mengamati subyek penelitiannya yaitu masyarakat Desa Anggris.

Penelitian dilaksanakan di Desa Anggris Rt. 003 Rw. 001, Kabupaten Tangerang. Lokasi ini sangat strategis karena peneliti sendiri tinggal didaerah ini sehingga peneliti dapat mengamati secara langsung setiap saat. Kampung Anggris memiliki keunikan menurut sudut pandang peneliti yaitu kampung yang banyak diapit oleh perumahan-perumahan elit dan dilengkapi fasilitas umum yang lengkap dan bagus, namun desa ini semakin tergerus habis oleh pembangunan di sekitarnya sehingga dikhawatirkan makin lama makin habis pemikiman penduduk aslinya.

\section{Alat Pengumpulan Data}

Alat yang digunakan mengumpulkan data adalah buku catatan dan alat tulis, alat perekam, serta kamera. Buku catatan dan alat tulis digunakan untuk mencatat informasi ketika melakukan studi pustaka, mencatat informasi dari narasumber dalam melakukan wawancara, dan mencatat informasi ketika melakukan observasi. Alat perekam digunakan untuk merekam informasi dari narasumber ketika melakukan wawancara. Kamera digunakan untuk mendokumentasikan kegiatan observasi di lapangan.

\section{Analisis Data}

Adapun langkah-langkah pengolahan data penelitian kualitatif adalah sebagai berikut :

1. Reduksi data, pada tahap ini, data yang terekam, terkumpul, dan 
terangkum dalam catatan lapangan (field notes) diseleksi. Data-data yang telah diseleksi disusun kedalam berbagai kategori atau fokus permasalahan.

2. Penyajian data, pada tahap ini, data selanjutnya diolah dengan menyusun atau menyajikan data kedalam matriks-matriks yang sesuai dengan hasil penelitian.

3. Verifikasi/penarikan kesimpulan, pada tahap ini, setelah data direduksi dan disajikan dalam matriks, peneliti mencari kesimpulan dari data tersebut.

\section{Pengecekan Keabsahan Temuan}

Untuk menetapkan keabsahan (trustworthiness) data diperlukan teknik pemeriksaan.Pelaksanaan teknik pemeriksaan didasarkan atas sejumlah kriteria tertentu. Ada 4 (empat) kriteria yang digunakan, lihat tabel berikut:

1. Derajat kepercayaan (credibility),

2. Keteralihan (transferability),

3. Kebergantungan (dependability),

4. Kepastian (confirmability),

\section{Tahap-Tahap Penelitian}

1. Tahap Pra-Lapangan (Studi Pendahuluan)

2. Tahap pekerjaan lapangan

3. Tahap analisis data

4. Tahap pelaporan hasil
a. Bentuk laporan penelitian.
b. Kerangka dan isi laporan.
c. Teknik dan strategi penulisan laporan.
d. Penelaahan hasil penulisan.
e. Penulisan karya ilmiah.

\section{Paparan Data}

\section{Deskripsi lokasi penelitian}

Penelitian ini dilakukan di kampung Anggris Rt. 003/001, Desa Medang, Kecamatan Pagedangan, Kabupaten Tangerang. Berikut adalah gambaran mengenai lokasi penelitian.

a. Kondisi Umum

Penelitian dilakukan di Kampung Anggris, Desa/Kelurahan Medang, Kecamatan Pagedangan, Kabupaten Tangerang.

\section{Sejarah lokasi penelitian Desa/Kelurahan Medang}

Desa/Kelurahan Medang terbentuk pada tahun 1983 yang merupakan pemekaran dari Desa Bojongnangka bagian dari wilayah Kecamatan Legok, yang sebelumnya sudah menjadi desa persiapan pada tahun 1982. Maka pada tahun 1983 tersebut dilaksanakan pemilihan calon kepala desa pertama untuk memilih kepala desa Medang definitif.

\section{Temuan Penelitian}

\section{Temuan Data Penelitian}

a. Tingkat pendidikan rendah

b. Faktor keluarga

c. Faktor Lingkungan Masyarakat

d. Tingkat Perekonomian Keluarga

e. Tingkat Kebutuhan keluarga

f. Upah rendah

\section{HASIL DAN PEMBAHASAN}

\section{Faktor Tingkat pendidikan rendah} Rendahnya pendidikan yang terdapat pada masyarakat miskin yang ada di Kampung Anggris itu disebabkan oleh kurangnya 
dukungan dari pihak keluarga sehingga kesadaran untuk melanjutkan pendidikan ke jenjang yang lebih tinggi itu cenderung rendah, arti pentinya pendidikan tidak ditanamkan sejak dini oleh pihak keluarga ditambah rata-rata orang tuanya juga memiliki riwayat pendidikan yang rendah pula sehingga hal ini dianggap hal yang wajar-wajar saja.

\section{Faktor sosial budaya masyarakat}

Kebutuhan yang terkait sosial dan budaya sangatlah beragam macam dan jenisnya sehingga dalam pemenuhannya ada rasa keterikatan pada keharusan dan keyakinan, sehingga masing-masing individu merasa wajib memenuhi kebutuhan ini, hal ini yang merupakan penyebab kemiskinan individu jika kebutuhan dasarnya saja tidak dapat mereka penuhi terlebih adanya kebutuhan sosial dan budaya.

\section{Faktor Upah minimum}

Masyarakat miskin Kampung Anggris memiliki pendapatan/upah yang rendah karena hal ini ditunjang dengan pekerjaan yang rendah pula, kebanyakan bekerja sebagai buruh angkut pasir bagi kaum laki-laki dan buruh cuci bagi kaum wanitanya, sementara upah yang mereka dapatkan tidak menentu karena dalam kinerja mereka tidak diperhitungkan profesionalisme dan lamanya bekerja, hal ini mempengaruhi kepada tingkat pemenuhan kebutuhan yang rendah karena ketidak berdayaan mereka untuk memenuhinya.

\section{KESIMPULAN}

Setelah penulis mengadakan penelitian dan pembahasan terhadap faktor-faktor yang mempengaruhi tingkat kemiskinan yang terdapat di Kampung Anggris, Desa Medang, Kabupaten Tangerang. Maka dapat disimpulkan sebagai berikut:

\section{Faktor Tingkat Pendidikan Rendah}

Faktor tingkat pendidikan rendah sangat berpengaruh sekali terhadap tingginya angka kemiskinan yang ada di Kampung Anggris, hal ini berdasarkan hasil pengamatan secara langsung dan wawancara yang sudah dilakukan oleh peneliti, terbukti dari rata-rata informan hanya menyandang pendidikan tingkat dasar dan rata-rata bekerja sebagai buruh, padahal fakta dilapangan Kampung Angri adalah kampung yang memiliki tingkat pertumbuhan ekonomi yang bagus, seperti apartemen, hotel dan rumah sakit terdapat di kampung ini, bahkan tempat-tempat usaha lain banyak tumbuh subur di daerah ini dengan demikian banyak sekali kesempatan kerja yang tersedia di kampung ini, namun seperti kita ketahui bahwa pendidikan merupakan kunci dasar untuk mendapatkan sebuah pekerjaan selain pengalaman, dengan demikian warga Kampung Anggris sendiri kalah bersaing dengan masyarakat pendatang yang memiliki riwayat pendidikan lebih baik. Dengan demikian faktor pendidikanlah yang membuat warga asli Kampung Anggris kehilangan kesempatan mendapatkan pekerjaan yang lebih 
baik sehingga tarap hidup mereka berada pada garis kemiskinan.

\section{Faktor Sosial Budaya Masyarakat}

Faktor sosial budaya masyarakat menjadi dampak pada tingginya angka kemiskinan yang terdapat di Kampung Anggris, karena adanya pengeluaran yang dianggap lebih penting dari pada konsumsi seharihari, yaitu kebutuhan untuk acaraacara terkait adat istiadat dan acaraacara terkait keagamaan serta kebutuhan yang mengikuti trend yang ada di masyarakat Kampung Anggris, sehingga mau tidak mau dan ada atau tidak ada mereka tetap harus menjalankannya atau mengeluarkannya untuk dua kebutuhan ini, secara tidak langsung mereka lebih mementingkan dua hal ini dibandingkan untuk konsumsi sehari-hari seperti untuk acara lamaran dan pernikahan, serta acara munggahan dan muludan dan acaraacara lainya, demi acara-acara semacam ini mereka rela menghutang demi memenuhi kebutuhan tambahan ini. Dengan demikian yang menyebabkan tingginya angka kemiskinan yang terdapat di Kampung Anggris sendiri adalah kebutuhan tambahan yang bersifat wajib dan mengikat, hal inilah yang membuat membengkaknya pengeluaran yang ada dan hal inilah yang mendorong semakin tingginya angka kemiskinan yang ada.

\section{Faktor Upah Rendah}

Upah minimum yang ditetapkan oleh pemerintah sebetulnya bertujuan kepada kesejahteraan masyarakatnya, namun banyak sekali pekerjaan yang memberikan upah dibawah standar yang dikeluarkan oleh pemerintah, seperti halnya yang terjadi di warga miskin Kampung Anggris, mereka mendapatkan upah dibawah rata-rata upah minimum yang sudah ditetapkan oleh pemerintah bahkan pendapatan mereka cenderung tidak menentu dalam sehari-harinya itu disebabkan pekerjaan mereka ratarata buruh serabutan yang tidak adanya aturan yang mengikat mengenai upah, pendapatan mereka berdasarkan pada ada tidaknya bongkar muat, bahkan dalam seharian bisa saja tidak ada, sementara kebutuhan dasar seharihari harus dipenuhi, dengan demikian tidak jarang mereka meminjam atau menghutang untuk memenuhi kebutuhan dasar mereka, semakin hari semakin menumpuk hutang mereka kalau pendapatan mereka sendiri saja tidak menentu, hal inilah yang menjadi dampak tingginya angka kemiskinan yang ada.

\section{REFERENSI}

Aditya, Sri. (2010). Analisis

Ketimpangan Wilayah dan

Faktor-faktor yang

Mempengaruhi dengan Model Panel Data (Studi Kasus 23

Kabupaten/Kota di Propinsi Jawa Tengah Tahun 2000-2007). Fakultas Ekonomi Universitas Diponegoro Semarang. 
Arsyad, Lincolin. (1999). Ekonomi

Pembangunan. Yogyakarta: STIE YKPN.

Bungin, Burhan H. M, (2001). Metodologi Penelitian Kualitatif dan Kuantitatif. Yogyakarta: Gajahmada Press.

Bungin, Burhan H. M, (2007). Penelitian Kualitatif: Komunikasi, Ekonomi, Kebijakan Publik, dan Ilmu Sosial. Jakarta: Kencana Pernama Media Group.

Badan Pusat Statistik. (2017). Kecamatan Pagedangan Dalam Angka 2017. Tangerang: BPS Kabupaten Tangerang.

Nasir. Muhamad, dkk. (2008). Analisis Faktor-faktor yang Mempengaruhi Kemiskinan Rumah Tangga di Kabupaten Purworejo. Eksekutif Vol. 5 No.2, Agustus 2008.

Raihana Kaplale. (2012). Faktorfaktor yang Mempengaruhi Tingkat Kemiskinan di Kota Ambon (study kasus di Dusun Keranjang Desa Waiyame Kec. Teluk Ambon dan Desa Waiheru Kec. Teluk Ambon Baguala Kota Ambon), Volume 1 No.1 oktober 2012. PS Agribisnis Faperta Unpattti. Ambon.

Rintuh, C. M,. (2003). Kelembagaan dan Ekonomi Rakyat. Jakarta: Dikti.

Rusdiarti dan Lista Karolina Sebayang. (2013). Faktor-faktor yang mempengaruhi tingkat kemiskinan di Provinsi Jawa Tengah. Jurnal Ekonomia. Vol.
9 Nomor 1, April 2013. UNNES. Semarang.

Sen, Amartya. (1981). Poverty and Faminas An Essay on Entitlement and Deprivation. Oxford: Clarendon Press.

Sukirno, Sadono. (2006). Pengantar Teori Ekonomi Makro. Jakarta: Raja Grafindo Persada.

Sukirno, Sadono. (2004). Makro Ekonomi. Jakarta: Raja Grafindo Persada.

Suryawati, Chriswardani. (2005). Memahami Kemiskinan Secara Multidimensional = Understanding

Multidimensional of Poverty. Jurnal Manajemen Pelayanan Kesehatan Volume VIII No. 3.

Tarigan, Robinson. (2004).

Perencanaan Pembangunan Wilayah. Jakarta: Bumi Aksara.

Tirtarahardja, Umar. (2008). Pengantar Pendidikan. Jakarta: Rineka Cipta.

Todaro, Michael P. (2003). Pembangunan Ekonomi di Dunia Ketiga Jilid 1. Jakarta: Erlangga.

Undang - Undang Sistem Pendidikan Nasional (UU SISDIKNAS) Nomor 20 Tahun 2003.

Undang - Undang Republik Indonesia Nomor 20 Tahun 2003 Tentang Sistem Pendidikan Nasional Bab 1 Pasal 1 Nomor 4.

Wardiyanta. (2010). Metode Penelitian Pariwisata. Edisi II. Yogyakarta: Andi Press. 